\title{
Development of an Assessment Tool for Agricultural Best Management Practice Implementation in the Great Lakes Restoration Initiative Priority Watersheds-Alger Creek, Tributary to Saginaw River, Michigan
}

\section{Introduction}

The Great Lakes face a number of serious challenges that cause damage to water quality, habitat, ecology, and coastal health. Excess nutrients from point and nonpoint sources have a history of causing harmful algal blooms (HABs); since the late 1990s, a resurgence of HABs have forced beach closures and resulted in water quality impairments across the Great Lakes. Studies increasingly point to phosphorus (P) runoff from agricultural lands as the cause of these HABs. In 2010, the Great Lakes Restoration Initiative (GLRI) was launched to revitalize the Great Lakes. The GLRI aims to address the challenges facing the Great Lakes and provide a framework for restoration and protection. As part of this effort, the Priority Watersheds Work Group (PWWG), cochaired by the U.S. Environmental Protection Agency (EPA) and the U.S. Department of Agriculture-Natural Resources Conservation Service (USDA-NRCS), is targeting Priority Watersheds (PWs) to reduce the amount of P reaching the Great Lakes. Within the PWs, USDA-NRCS identifies small-scale subbasins with high concentrations of agriculture for coordinated nutrient reduction efforts and enhanced monitoring and modeling. The USDA-NRCS supplies financial and/or technical assistance to producers to install or implement best management practices (BMPs) to lessen the negative effects of agriculture to water quality; additional funding is provided by the GLRI through USDA-NRCS to saturate the small-scale subbasins with BMPs. The watershed modeling component, introduced in this fact sheet, assesses the effectiveness of USDA-NRCS funded BMPs, and nutrient reductions because of GLRI or other funding programs are differentiated. Modeling scenarios consider BMPs that have already been applied and those planned to be implemented across the small-scale subbasins.

\section{Alger Creek Description}

Within Michigan, the Priority Watershed of interest is the Saginaw River watershed. It is in east-central Michigan and drains into Saginaw Bay, which is part of Lake Huron. The small subbasin that has been selected for this increased nutrient reduction effort, monitoring, and BMP assessment is Alger Creek subbasin (also locally known as Kimball Drain; fig. 1). This rural, 20-square-mile $\left(\mathrm{mi}^{2}\right)$ subbasin is entirely within Genesee

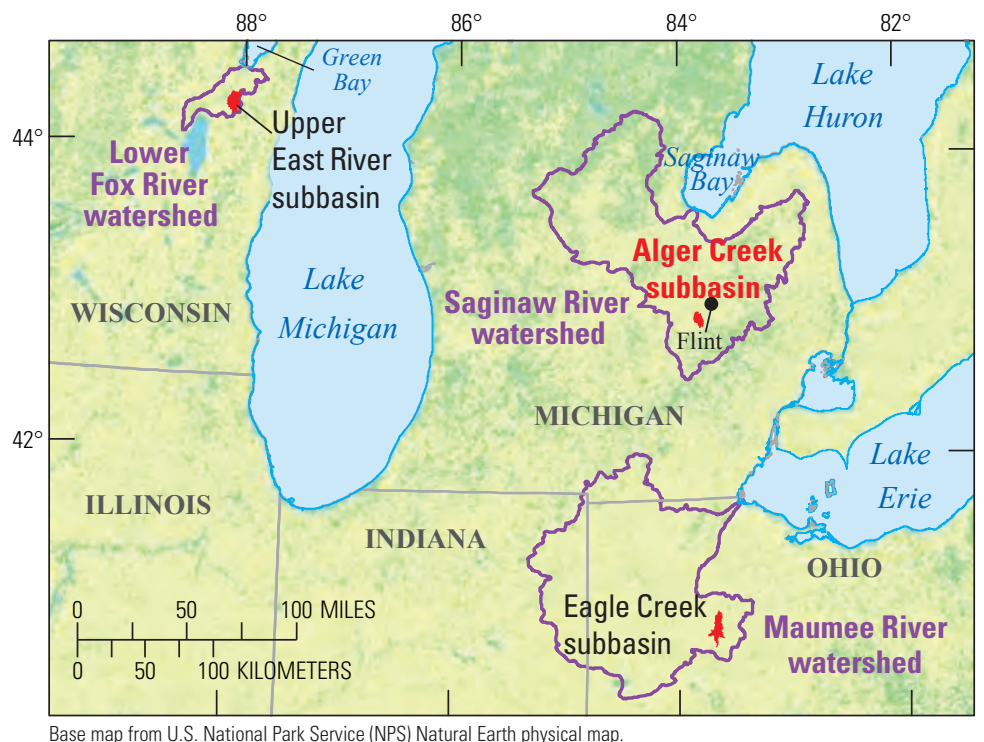

Figure 1. Priority watersheds (purple) and study subbasins of interest (red), the Great Lakes area.
County, Mich., southwest of the city of Flint, Mich. (fig. 2). About 40 percent of the land-use area is used for agricultural production (table 1; fig. 3). Primary crops grown in this watershed are corn and soybeans.

\section{Best Management Practices}

Producers within the Alger Creek subbasin have received extensive funding through the GLRI and existing authorities provided to USDA-NRCS by the Farm Bill to implement BMPs to improve the water quality of agricultural runoff. Commonlyfunded BMPs are listed in table 2. The most commonly used conservation crop rotation is a 2-year cycle of corn-soybean (USDA Natural Resources Conservation Service, oral commun., 2014). Additionally, two other different crop rotations are common: (1) a 3-year rotation of corn-soybean-winter wheat and (2) multiple-year rotation of corn-soybean-corn-soybean-hay. Hay is grown for 5-6 years following the last harvest of soybeans in the rotation. When cover crops are used in rotation, they typically are planted after winter wheat and soybeans, not corn. Cereal rye is a typical cover crop in winter, and it can be planted as late as November.

\section{Monitoring Data}

The U.S. Geological Survey (USGS) installed one edgeof-field (EOF) gaging station (0414826544) within the Alger Creek subbasin for monitoring nutrient loads in surface runoff. Collocated with this gaging station, subsurface tile drain flow (0414826545) is also monitored. Daily and annual nutrient 
Table 1. Land use for the Alger Creek subbasin, Michigan (from U.S. Department of Agriculture, National Agricultural Statistics Service, 2013).

\begin{tabular}{lcc}
\hline \multicolumn{1}{c}{ Land use } & $\begin{array}{c}\text { Flint River } \\
\text { land use } \\
\text { (percent) }\end{array}$ & $\begin{array}{c}\text { Alger Creek } \\
\text { land use } \\
\text { (percent) }\end{array}$ \\
\hline Deciduous forest & 24 & 17 \\
Grass/pasture & 17 & 27 \\
Soybeans & 12 & 24 \\
Corn & 10 & 9 \\
Developed/open space & 10 & 5 \\
Developed/low intensity & 7 & 6 \\
Woody wetlands & 7 & 3 \\
Winter wheat & 4 & 2 \\
Alfalfa & 3 & 4 \\
Developed/medium intensity & 2 & 1 \\
Open water & 1 & $<1$ \\
Developed/high intensity & 1 & $<1$ \\
Fallow/idle cropland & $<1$ & $<1$ \\
Other & $<1$ & \\
\hline
\end{tabular}

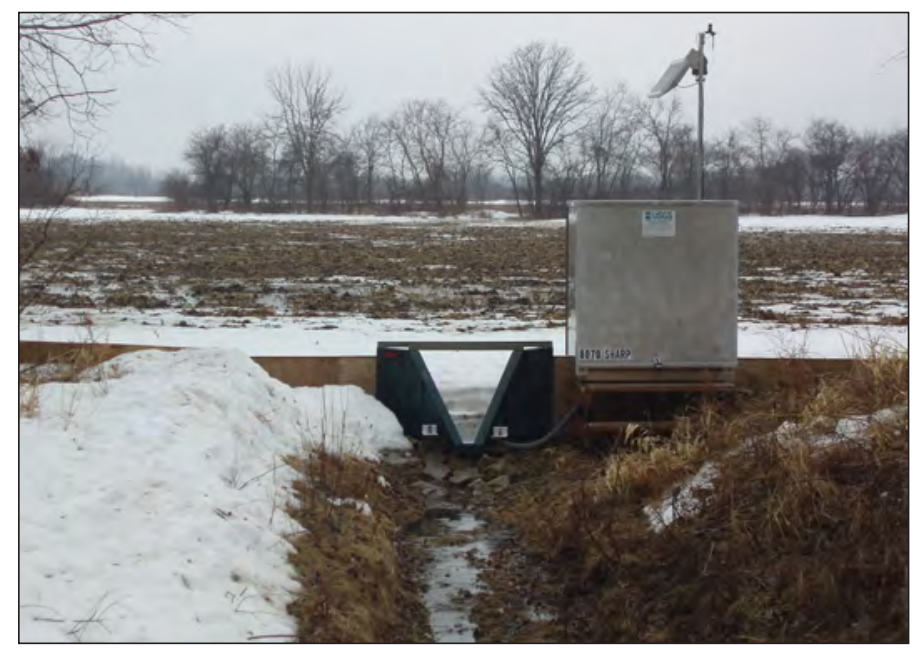

Photo by Katherine Merriman, USGS.

Table 2. Most contracted best management practices (BMPs) through the U.S. Department of Agriculture-Natural Resources Conservation Service Farm Bill conservation programs in the Alger Creek subbasin, Michigan (in alphabetical order from the National Conservation Planning Database, David Butler, U.S. Department of Agriculture-Natural Resources Conservation Service, written commun., 2015).

\section{Best management practice}

Conservation crop rotation.

Cover crop.

Forest stand improvement.

Nutrient management.

Residue management, reduced till.

Residue management, no-till. loadings are computed with the Graphical Constituent Loading Analysis System (GCLAS; Koltun and others, 2006). The monitored field is targeted for the implementation of a nutrient management plan as a BMP.

\section{Assessment Tool Development}

A Soil and Water Assessment Tool (SWAT) model is in development for simulating the effects of GLRI BMPs on nutrient loadings in the Alger Creek subbasin. This model is to help demonstrate the potential benefits BMPs have in reducing nutrient loading from agricultural fields. The SWAT model is an empirically based model that simulates hydrology and water quality on a daily basis (Neitsch and others, 2011). Site-specific BMP information has been received from the USDA-NRCS National Conservation Practice Database from applied practices 2004 to 2014, and planned practices from present (2015) until 2018 through a Memorandum of Understanding (MOU) and coordination with USDA-NRCS. The USDA-NRCS field-level staff are supplying additional information on BMPs, such as: timing of operations, type and amounts of fertilizer or manure applied, and harvest dates and yields. These data are for setup and calibration of the model. Fertilizer application rates for the model were based on conversations with local USDA-NRCS staff and recommendations found in Vitosh and others (1995). Soils within the Alger Creek subbasin are somewhat poorly to poorly drained (Soil Survey Staff, Natural Resources Conservation Service, U.S. Department of Agriculture, 2014), and an unknown amount of the Alger Creek subbasin contains tile drains to increase field drainage and improve crop yields during the growing season. Tile drainage extents are being estimated based on land use, soil type, and land slope. Modeling inputs are detailed in table 3 .

The SWAT model calibration and validation is for hydrology and water quality parameters (sediment, phosphorous, and nitrogen). The gaging station at the Alger Creek subbasin outlet (041482663; fig. 2A), installed in April 2012, does not currently (2015) have a period of record long enough for an accurate calibration for the SWAT model. Because the period of record lacks weather variability, some of the resulting hydrology and water quality trends could be missed. In order to have a longer period of record for hydrology and water quality calibration, the model extent was enlarged to the downstream outlet of the Flint River (fig. 2B). This allows the model to be calibrated to the hydrology record at the Flint River near Fosters, Mich., gaging station (04149000). Sporadic grab samples were collected at this site throughout August 2000-September 2013, not including the winter seasons. Grab sample data are being converted to daily loads by using the Load Estimator (LOADEST) program (http:// water.usgs.gov/software/loadest/), which requires concentration data and times-series streamflow data. Hydrology collection at the Flint River near Fosters, Mich., gaging station was discontinued in October 2011; subsequently, loads can only be calculated with LOADEST at the site from 2000 to 2011 when streamflow data are available. The period of record for water quality calibration is, therefore, 2004-2011 and for water quality validation is 2000-2003, not including the winter season. There are several hydrology-only gaging stations within the Flint River watershed; additional model calibration and validation details for other sites are listed in table 3. Site-specific, intensive agricultural 


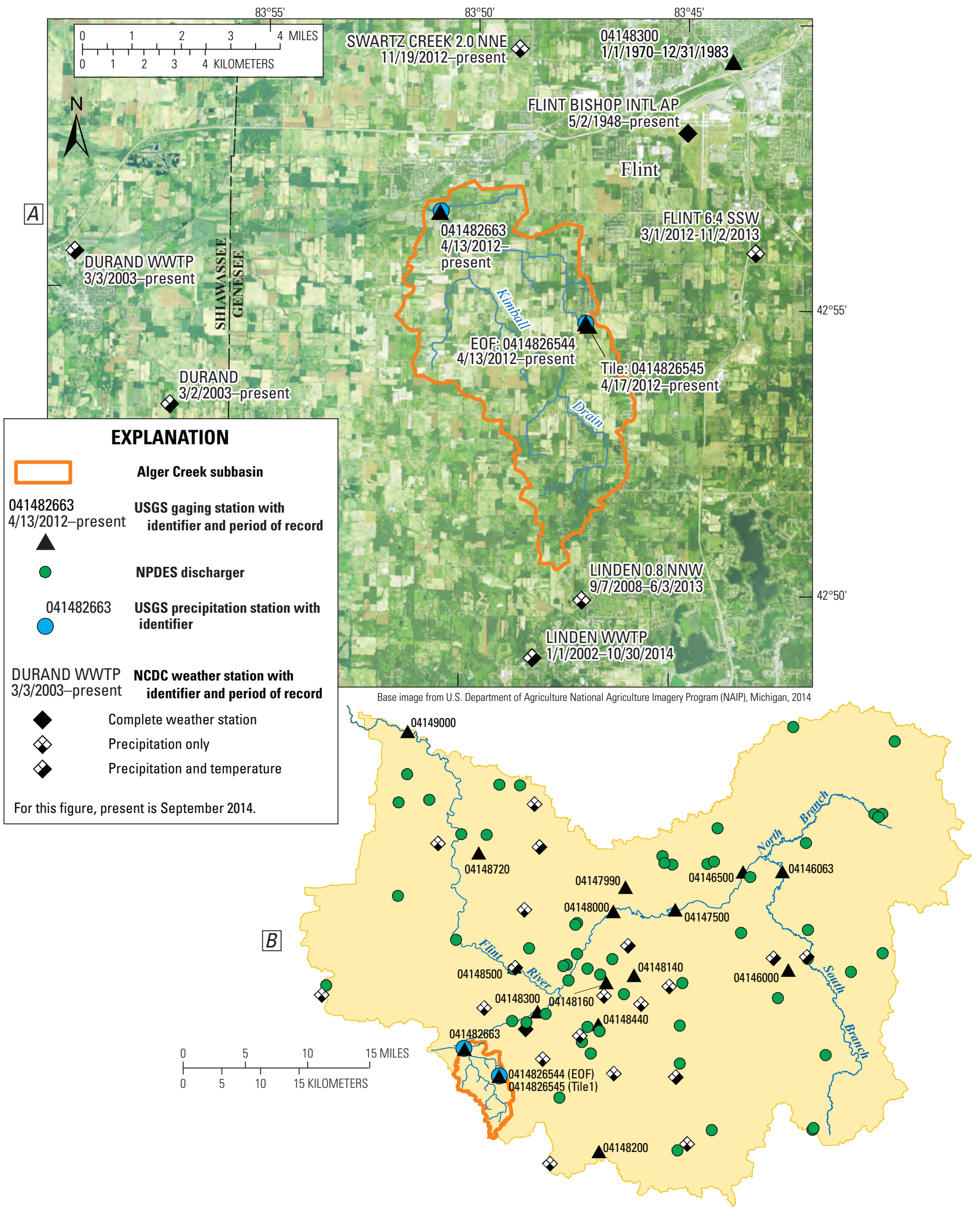

Figure 2. Locations of U.S. Geological Survey (USGS) gaging stations, National Pollutant Discharge Elimination System (NPDES) sites, and National Climatic Data Center (NCDC) weather stations in A, Alger Creek subbasin; and B, Flint River watershed, Michigan. 
EXPLANATION

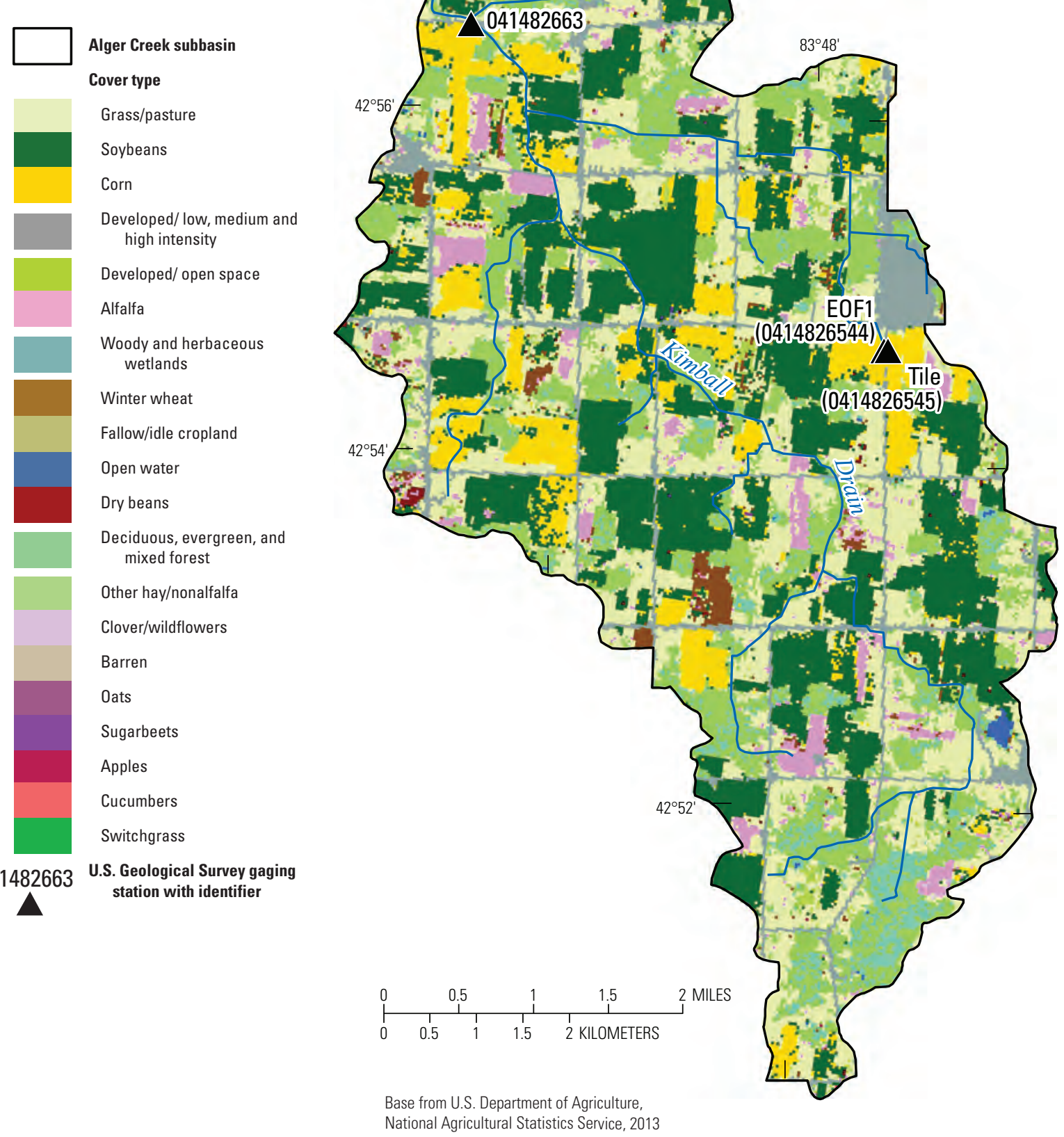

Figure 3. U.S. Geological Survey gaging stations and land use in the Alger Creek subbasin, Michigan.

management practices derived from the USDA-NRCS National Conservation Practice Database are to be simulated within the Alger Creek subbasin.

These models are assessment tools to determine the effect agricultural BMPs have on reducing nutrient loads at the field and small watershed scale in the Alger Creek subbasin. Initial model runs simulate current practices and differentiate between GLRI and non-GLRI funded practices. Additional model scenarios target specific BMPs, as determined with input from local and state USDA-NRCS agents at different implementation levels. Candidate BMPs for the Alger Creek subbasin model include those listed in table 2. Subbasin-specific information about the BMPs, including timing and quantity of fertilizer application, species of cover crops, typical crop rotation, etc., for the Alger Creek subbasin is being collected at this time (2015) to help determine how to incorporate these BMPs into the SWAT model. 
Table 3. Soil and Water Assessment Tool Modeling Parameters for the Alger Creek subbasin and Flint River watershed, Michigan.

[HUC, hydrologic unit code; ID, identification; $\mathrm{mi}^{2}$, square mile; SWAT, soil and water assessment tool; CAFO, confined animal feeding operation; NPDES, National Pollutant Discharge Elimination System]

\begin{tabular}{ll}
\multicolumn{1}{c}{ Parameter } & \multicolumn{1}{c}{ Item/data source } \\
\hline HUC 8 ID & 04080204 Flint River basin \\
HUC 12 ID & 040802040301 Alger Creek subbasin \\
Flint River area & $1,330 \mathrm{mi}^{2}(851,488$ acres $)$ \\
Alger Creek priority area & $20.08 \mathrm{mi}^{2}(12,856$ acres $)$
\end{tabular}

Constructed from site-specific management data provided U.S. Department of Agriculture-Natural

Land use Resources Conservation Service combined with common land unit field boundaries and the U.S. Department of Agriculture, National Agricultural Statistics Service (2013).

Soils

Soil Survey Geographic (SSURGO) database (Soil Survey Staff, Natural Resources Conservation Service, U.S. Department of Agriculture, 2014). (http://datagateway.nrcs.usda.gov/)

Weather

National Climatic Data Center for precipitation and temperature (http://www.ncdc.noaa.gov). All other weather data were simulated by the Soil and Water Assessment Tool built-in weather generator from averages from the nearby station at the Flint Bishop Airport including the following: wind speed, solar radiation, and relative humidity.

USGS Water Data (http://waterdata.usgs.gov/nwis).

Alger Creek at Hill Road near Swartz Creek, MI (041482663), April 2012-present (2015).

Farmers Creek near Lapeer, MI (04146000), April 1933-present (2015).

Gages used for hydrology calibration Flint River near Fosters, MI (04149000), October 1939-October 2011. and period of record available

Flint River near Flint, MI (04148500), August 1932-present (2015).

Flint River near Otisville, MI (04147500), October 1952-present (2015).

Kearsley Creek near Davison, MI (04148140), October 1965-present (2015).

South Branch Flint River near Columbiaville, MI (04146063), March 1980-present (2015).

Gages used for hydrology validation

Select years from Flint River near Fosters, MI (04149000) and Flint River near Flint, MI (04148500).

Gages used for water quality calibration and period of record

Gages used for water quality validation and period of record

Number of CAFOs

NPDES discharge
Flint River near Fosters, MI (04149000) gage. Loads will be calculated with the Load Estimator (LOADEST) from sporadic grab samples collected from 2004 to 2011 and streamflow measurements. Alger Creek at Hill Road near Swartz Creek, MI (041482663), daily loads, April 2012-present (2015).

Flint River near Fosters, MI (04149000) gage. Loads will be calculated with LOADEST from sporadic grab samples taken from 2000 to 2003 and streamflow measurements.

There are no permitted CAFOs within Alger Creek or the Flint River watershed.

US. Environmental Protection Agency, Enforcement and Compliance History Online (ECHO), (2014) (http://echo.epa.gov/).There are no permitted dischargers within Alger Creek subbasin; however, there are 57 within the Flint River basin.

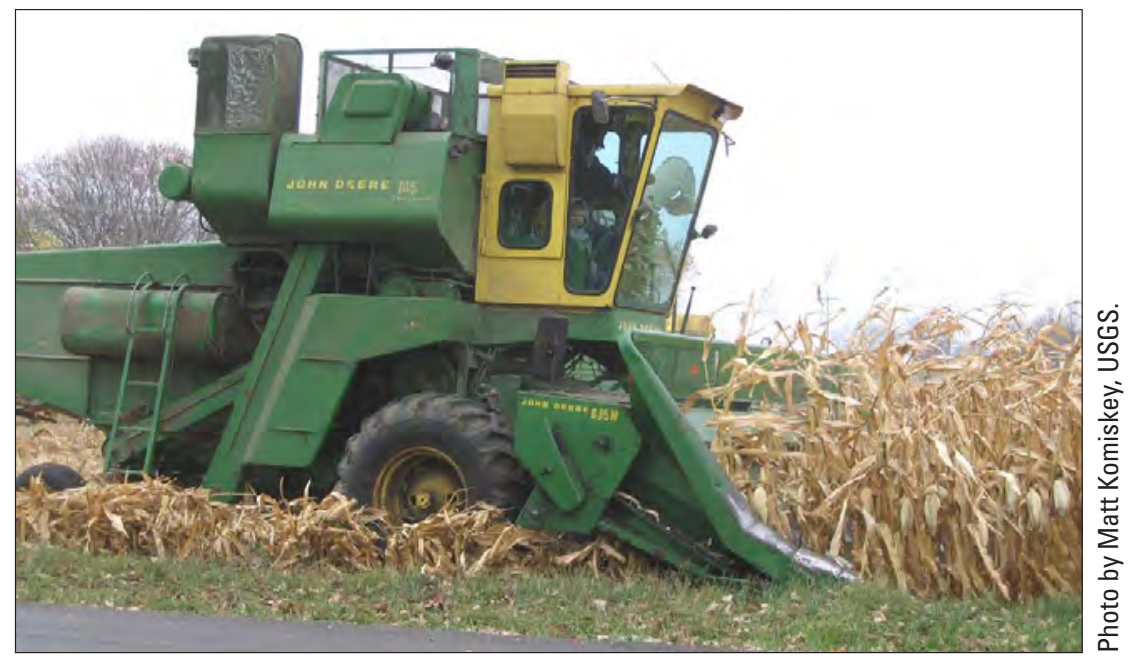




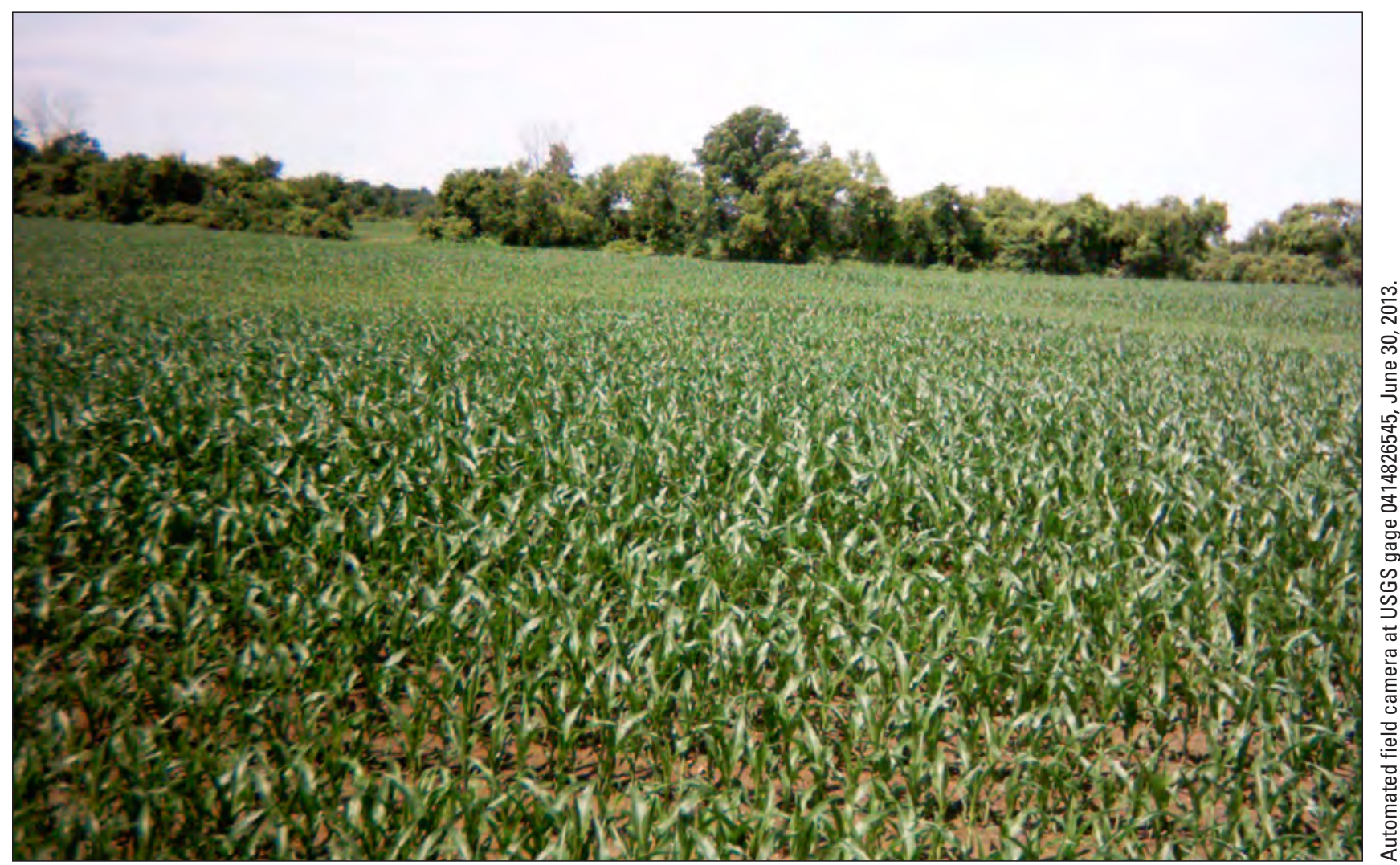

\section{References Cited}

Koltun, G.F., Eberle, M., Gray, J.R., and Glysson, G.D, 2006, User's manual for the Graphical Constituent Loading Analysis System (GCLAS): U.S. Geological Survey Techniques and Methods, book 4, chap. C1, 51 p. [Also available at http://pubs.usgs.gov/tm/2006/tm4C1/.]

Neitsch, S.L., Arnold, J.G., Kiniry, J.R., and Williams, J.R., 2011, Soil and Water Assessment Tool-Theoretical documentation version 2009: College Station, Texas, Texas Water Resources Institute Technical Report 406, Texas A\&M University System. [Also available at http://swat.tamu.edu/ media/99192/swat2009-theory.pdf.]

Soil Survey Staff, Natural Resources Conservation Service, U.S. Department of Agriculture, 2014, U.S. general Soil Survey Geographic (SSURGO) database: accessed September 16, 2014, at at http://sdmdataaccess.nrcs.usda.gov/.

U.S. Department of Agriculture, National Agricultural Statistics Service, 2013, CropScape-Cropland data layer: accessed May 6, 2014, at http://nassgeodata.gmu.edu/CropScape/.
Vitosh, M.L., Johnson, J.W., and Mengel, D.B., eds., 1995, Tristate fertilizer recommendations for corn, soybeans, wheat and alfalfa: Extension Bulletin E-2567, 22p. [Also available at https://www.extension.purdue.edu/extmedia/AY/AY-9-32. pdf.]

Suggested citation:

Merriman, K.R., 2015, Development of an assessment tool for agricultural best management practice implementation in the Great Lakes Restoration Initiative priority watersheds-Alger Creek, tributary to Saginaw River, Michigan: U.S. Geological Survey Fact Sheet 2015-3067, 6 p., http://dx.doi.org/10.3133/ fs20153067.

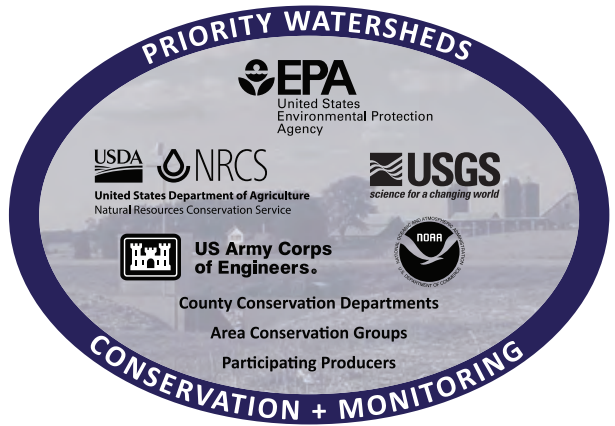

\section{For more information contact:}

Director, Illinois Water Science Center U.S. Geological Survey 405 N. Goodwin Ave.

Urbana, IL 61801

http://il.water.usgs.gov

\section{Author:}

Katherine R. Merriman

\section{Related reports:}

http://dx.doi.org/10.3133/fs20153065/

http://dx.doi.org/10.3133/fs20153066/ 